\title{
BIOÉTICA \\ DIREITOS DO NASCITURO, DIREITOS DAS GERAÇÕES FUTURAS ${ }^{12}$
}

PROF. DR. FANCESCO RIMOLI ${ }^{3}$

\begin{abstract}
RESUMO: O artigo aborda, sob o ponto de vista da bioética, as biotecnologias como substrato para a criação de novos direitos. São discutidos alguns problemas legislativos na Europa, bem como a questão da definição do início e do fim da vida humana, da reprodução assistida e direito à procriação, da eutanásia, do aborto e do direito à vida; todos sob o panorama da proteção dos direitos fundamentais.

PALAVRAS-CHAVE: Bioética; Fecundação Assistida; Direitos das Gerações Futuras.

ABSTRACT: From the point of view of bioethics, the article approaches biotechnologies as substance for the acknowledgment of new rights. It discusses some regulation problems in Europe, as well as the issue of defining the beginning and end of human life, assisted reproduction and right to procreation, euthanasia, abortion and right to life; all under a theory of fundamental rights protection. KEYWORDS: Bioethics; Assisted Reproduction; Future Generation's Rights.

SUMÁRIO: 1 A Definição Geral do Problema: a bioética como tema específico da filosofia moral; 2 O Desenvolvimento das Biotecnologias impõe a Criação de "novos direitos"?; 3 A Intervenção Legislativa: problemas gerais; 4 Bioética, Direito e Vida Humana: os problemas do início e do fim da existência individual; 5 A Experiência Genética e os Direitos das Gerações Futuras; 6 Biotecnologias e Mercados: os riscos dos oligopólios; Referências Bibliográficas.

SUMMARY: 1 The General Definition of the Problem: bioethics as a specific field of moral philosophy; 2 Does the Development of Biotechnologies impose the Acknowledgment of "new rights"?; 3 Legislative intervention: general problems; 4 Bioethics, Law and Human Life: the issues of the beginning and end of individual existence; 5 Genetic Experience and the Rights of Future Generations; 6 Biotechnologies and Markets: the risks of oligopolies; Bibliographical References.
\end{abstract}

\footnotetext{
Artigo recebido em 01.11.2011. Artigo aceito para publicação em 12.03.2012 mediante convite. ${ }^{1} \mathrm{O}$ presente artigo foi publicado originalmente na Itália: Bioetica - Diritti del Nascituro Diritti delle Generazioni Future. In NANIA, Roberto; RIDOLA, Paolo. I Diritti Costituzionali. Volume II, 2. ed., Torino: G. Giappichelli Editore, 2006. Pág. 527-557.

${ }^{2}$ Artigo Traduzido por Ana Clara da Rosa Alves, Mestranda em Direito pela PUCRS.

${ }^{3}$ Diretor do Departamento de Direito Público da Universidade de Teramo (Itália).frimoli@unite.it
} 
1 A DEFINIÇÃO GERAL DO PROBLEMA: A BIOÉTICA COMO TEMA ESPECÍFICO DA FILOSOFIA MORAL

O rápido e impressionante desenvolvimento das biotecnologias conduziu, nas últimas décadas, a atenção da opinião pública e dos estudiosos de ciências sociais a uma série de problemas teóricos, mas sobretudo práticos, de notável complexidade. Na verdade, trata-se principalmente de impressões atuais relativas às temáticas que são, todavia, tradicionalmente próprias da reflexão ética e que se concentram nas definições e nos limites temporais, iniciais e finais, da vida humana, e também sobre a capacidade e licitude moral de intervenção direta do homem sobre a sua própria existência concreta e a dos outros. Sobre esses difíceis conceitos entrelaçam-se, como é óbvio, grande parte dos preceitos religiosos e jurídicos, ou ainda a reconstrução filosófica que caracterizam qualquer civilização. A atividade médica revelou, desde a antiguidade uma constante necessidade de sistematização sobre o plano ético; o íntimo contato com os eventos de nascimento e morte requer ao médico e à sociedade que the confia determinadas tarefas, a elaboração mais ou menos determinada de códigos de conduta que vão, de qualquer modo, aliviar a responsabilidade de escolhas que, de outro modo, seriam ao indivíduo, frequentemente, insustentáveis. Assim, na tradição grega como na hebraica e, mais tarde, na católica, o problema ético da atividade médico-sanitária foi afrontado pela determinação de um número considerável de imposições e proibições, fundadas, em parte, sobre a aquisição de experiências concretas e sobre a consequente elaboração de regras de higiene, mas em outro e talvez principal aspecto, sobre a projeção imediata de convicções e credos religiosos, que, por vezes, tornaram mais lento ou até mesmo impediram o desenvolvimento real do progresso científico e a melhora das condições de vida dos pacientes individuais (sobre o tema veja-se o volume de vários autores Bioetica e grandi religioni, organizado por S. SPINSANTI, Cinisello Balsamo 1987, que traduz algumas opiniões da grande Encyclopedia of Bioethics, publicada em 1978 pela Universidade de Georgetown). A surpreendente ampliação das possibilidades de intervenção sobre as origens da própria vida, produzida recentemente pelos progressos da biologia celular e da engenharia genética, fez assim ressurgir, junto das legítimas dúvidas postas por qualquer operador consciente e racional, os numerosos integralismos dogmáticos das diversas tradições religiosas, que buscam de qualquer forma manter ou reafirmar a própria influência direta também sobre as escolhas dos legisladores, traduzindo em posição juridicamente obrigatória, e assim impondo de forma autoritária, a própria visão dos problemas em questão, constituída, muitas vezes, em soluções tanto claras quanto irracionais.

$\mathrm{Na}$ realidade, uma leitura unívoca dos problemas gerados pela bioética (o termo é de cunho recente, e começa a circular nos primeiros anos da década de 70: veja-se sobre o ponto J.R. Nelson, chamado Bioetica, 
in Enc. Novecento, Supplementi, I, Roma 1998, 127 ss.) é certamente impossível em termos absolutos; uma perspectiva do gênero, fundada sob uma dimensão ética estritamente cognitivista, mais ou menos fundada em concepções transcendentes, deve ser definitivamente rejeitada, de um lado pela sua substancial incompatibilidade com o contexto pluralista dos modelos democráticos dentro dos quais normalmente se inserem as nossas reflexões, e por outro, pela sua manifesta incapacidade de enfrentar os problemas postos, aqui com particular saliência, a partir do tecido multicultural da sociedade contemporânea, onde sempre mais difícil é atingir o objetivo de uma aceitação geral das opções individuais.

Diante da multiplicidade de perspectivas éticas e das dimensões religiosas, de fato, se põe em toda a sua complexidade o problema da fundação de uma ética laica, capaz de se fazer aceitar, até que possível, pelo consenso espontâneo, e sem o recurso à força: se recupera aqui aquela ideia de acordo como fundamento da ética coletiva que, de outra forma, foi recebida também nos mais aprofundados estudos do setor (veja-se entre estes o volume de H.T. ENGELHARDT Jr., Manuale di bioetica [1986], trad. it. Milano 1991, 25 ss.; porém, com diversa e mais ampla perspectiva, aliás não desprovido de tendência pós-cognitivista, recorda-se também a ideia de overlapping consensus de J. RAWLS, Liberalismo político [1993] trad. it. Milano 1994, 168 ss., ou o modelo discursivo de J. HABERMAS, Etica del discorso [1983], trad. it. Roma Bari 1990, e mais recentemente Fatti e norme. Contributi per una teoria discorsiva del diritto e della democrazia [1992], trad. it. Milano 1994).

Na realidade, no campo aqui levado em consideração não podem não agir critérios que, sob o plano da racionalização científica, se configuram como aplicações do modelo utilitarista clássico. Assim, o encontro entre custos e benefícios da ação, em uma avaliação orientada essencialmente sobre as consequências da mesma, representa um dos cânones essenciais da ação bioética, como daquela clínica. Quatro princípios são ainda comumente considerados na base de tais setores de atividade (sobre o ponto J.R. NELSON, op. cit., 129): a autonomia aqui entendida como conservação da capacidade de escolha do paciente em relação ao tratamento a realizar, e às vezes prevalente sobre o melhor interesse do mesmo, sedimentado do ponto de vista estritamente clínico (H.T. ENGELHARDT, op. cit., 80 ss.); a beneficência, concebida como intenção do operador de "fazer o bem" do paciente, segundo um critério concreto obviamente muito variável, e ainda avaliável somente a posteriori; o não malefício, entendido como obrigação de não piorar a situação do próprio paciente, com intervenções danosas ou com a simples inação quando esta possa produzir efeitos negativos; e enfim a justiça, obtida como expressão dos modelos de igualdade e equidade, particularmente pelo que se refere ao acesso ao tratamento médico, e ainda estritamente conexa à dimensão institucional do Estado Social e à atuação do direito fundamental à saúde garantido a todos os cidadãos em condições iguais. Tais princípios, 
todavia, não parecem, se não em sentido muito amplo, capazes de guiar, pela sua substancial indeterminação e subjetividade aplicativa, à intervenção do operador clínico; em relação à manipulação genética, também os critérios devem contudo serem, pelo menos em alguns aspectos, diversos em relação àqueles que podem motivar às escolhas relativas à eutanásia ou à estratégia terapêutica, ou seja com cuidado em relação às intervenções a serem realizadas em sujeitos já existentes. Se sobrepõe, no âmbito da intervenção sobre o padrão genético, uma série de problemas, de difícil solução sob o plano jurídico, inerentes à configuração de direitos próprios do sujeito futuro, tais a criarem frequentes potenciais colisões: assim, só para fazer um exemplo, o direito à identidade genética, em dada condição, pode se contrapor ao direito à saúde e à sanidade individual, entendido como direito do indivíduo futuro de nascer livre de má-formações e patologias geneticamente elimináveis.

Dos problemas específicos inerentes aos fenômenos mais controversos, da licitude ética e jurídica do aborto à prática das várias formas de fecundação assistida, às dificuldades concretas de alcançar soluções aceitáveis em relação à eutanásia dos doentes terminais às novas e inquietantes perspectivas da clonagem animal e humana se dirá mais adiante; aqui se deve mais sublinhar que, em sede de definição teórica dos problemas, a recusa das posições jusnaturalistas clássicas, resultado, como dito, necessário pelo aspecto pluralista no qual as considerações aqui desenvolvidas devem se colocar, não podem induzir a expressão de notáveis perplexidades sobre a configuração de direitos, strictu sensu concebidos, cuja titularidade seja atribuída a sujeito ainda não existente. $\mathrm{Na}$ realidade, o uso do sujeito futuro constitui essencialmente um útil instrumento, para a fixação neojusnaturalista, para justificar a pretendida universalização e positivação jurídica das próprias opções éticas: o sujeito futuro é enfim a mera projeção de uma noção de "pessoa" que - particularmente para a moral católica, no nosso contexto muito influente - já impõe como resultado de certas opções de valores fundamentais, definindo-se primeiro como conceito deontológico. Assim, a referência mais ou menos direta, ao caráter "natura" ou "artificial" (ou ainda inatural) da intervenção operada pela ciência aparece hoje como um desgastado meio de persuasão, insustentável apesar disso sob o plano da ética da ação: enquanto concebido e completo pelo ser humano, que faz parte do reino natural, cada ato, por si, poderá se definir bom ou mau, justo ou equivocado sob o plano moral ou sob um plano teleológico (na cadeia meio-consequência-fim), mas em nenhum caso contrário às "regras" da natureza, cuja coercitividade, no caso de uma presumida "violação", é negada pelo mesmo fato da sua demonstrada derrogabilidade. E mais, também em uma perspectiva metafísico-transcendente, não é de fato demonstrável que, admitido que regras possam existir como tais, elas foram concebidas pelo Ser criador como vínculo ao qual a humanidade deve conformar-se, e não, mais, como obstáculo a superar, 
como "desafio à capacidade de transformação dos homens" (segundo uma aguda observação de H.T. ENGELHARDT Jr., op. cit., 48; sobre este aspecto seja permitido enviar a F. RIMOLI, Appunti per uno studio sul diritto allá procreazione, in Studi in onore di M. Mazziotti di Celso, II, Padova 1995, 465 ss.).

A avaliação ética, e através dessa, também àquela jurídica, dos fenômenos aqui considerados, deve ser, enfim desenvolvida sob a luz dos critérios de autonomia e responsabilidade dos indivíduos, por outro lado, bem mais compatíveis com os assuntos de fundo do sistema, e segundo um modelo ético utilitarista, baseado essencialmente na ponderação das vantagens e dos custos de cada escolha individual. O que não exclui absolutamente, mas ao invés, permite e impõe a recompreensão correta, do aspecto axiologicamente "forte" do valor da vida humana e animal, na categoria dos bens sobre os quais se opera uma valoração comparativa e um adequado balanceamento (sobre o tema, com coerentes aplicações, P. SINGER, Etica pratica [1979], trad. it. Napoli 1989). A construção de direitos atribuídos aos sujeitos futuros ou até para futuras gerações da humanidade (sobre o tema H. JONAS, II principio responsabilità. Un'etica per la civiltà tecnologica [1979], trad. it. Torino 1990, 10 ss.) deixa, todavia, subsistir muitas perplexidades, sobretudo pelo fato que, relativo a tais direitos, não pode ser manifestado pelos titulares presumidos alguma vontade em relação à modalidade de exercício. Assim, por exemplo, no caso da procriação, o direito à vida do nascituro poderá se constituir sob 0 pressuposto de valor positivo da mesma, como assunto dos pais ou da maioria dos interessados, ou ainda, como direito dos primeiros à reprodução, mas não poderá, entretanto, ser corretamente considerado como direito (nem interesse) absoluto do sujeito futuro à aquisição de um estado (a existência terrena) relativo ao qual o titular presumido não pode fazer outra coisa que não sucumbir às escolhas realizadas pelos outros, muito menos será sustentável, em abstrato, um direito das gerações futuras à aquisição da mesma existência, ou de gozar de determinadas condições ambientais. Talvez, a única tese sustentável em tal perspectiva poderia ser aquela que constrói tal presumido "direito" dos sujeitos futuros como direito dos sujeitos já existentes a obterem um certo tipo de ambiente (entendido em sentido amplo) para os próprios descendentes (com um exemplo concreto, um direito dos pais - sujeitos atuais - à terem boas condições de vida para os próprios filhos, entendido como corolário do mais genérico direito à procriação): mas se trataria mais de um interesse do que de um direito. Na realidade, diante de uma função aparentemente inóqua, se revela mais a assunção de oposições axiológicas vinculantes e próprias de tais concepções; se colocadas como fundamento da disciplina normativa no direito positivo, estas colidem com os princípios de expansão da autodeterminação individual, e também com o mesmo pluralismo ético fundante da democracia ocidental. Os fins perseguidos por tais reconstruções, pelo menos para 
a parte que não se apresenta como subreptícias tentativas de imposição ideológica de concepções religiosas, são, todavia, partilháveis, mas devem ser agrupadas de outra forma: assim, por exemplo, o objetivo da conservação do ambiente, seja na sua saúde, seja, antes de tudo, em sua existência primária (pense-se não somente nas muitas formas de poluição, mas na hipótese extrema de destruições derivadas de guerras nucleares), pode ser impedido na ação dos sistemas democráticos, sem contradizer a abertura e o pluralismo, em virtude do caráter de irreversibilidade das escolhas que a tais ações são subjacentes (sobre o ponto N. LUHMANN, Stato di diritto e sistema sociale [1971], trad. it. Napoli 1990, 63 ss.; G. ZAGREBELSKY, II «crucifige» e la democrazia, Torino 1995, 100 ss.; F. RIMOLI, Pluralismo e valori costituzionali. I paradossi dell'integrazione democratica, Torino 1999, 181 ss.). Igualmente se poderá dizer para algumas formas de engenharia genética, cujos resultados se apresentam como imodificáveis para as próximas gerações, isso, no entanto, não porque nessas últimas - que ainda não existem possa se referir um direito de revisão das escolhas já realizadas por aqueles que lhes precederam, mas porque, dentro do atual sistema, no qual aquelas escolhas foram feitas, o princípio de reversibilidade pode constituir um limite geral nos conteúdos das mesmas escolhas, entendido como garantia da possibilidade de repetição das opções, antes de tudo, pela geração existente.

Por outro lado, apenas nessa perspectiva pode ser garantida a convivência de concepções existenciais entre elas diferentes e muitas vezes contrapostas, como aquelas que se sobrepõem na mescla de várias culturas; diante das dificuldades de racionalização dos problemas essenciais individual da existência humana, daquele da vida, do seu início, do seu fim, da quantidade e da qualidade da mesma, uma disciplina jurídica deve, no contexto pluralista e relativista da sociedade multiétnica, criar condições para uma coexistência pacífica com o reconhecimento do outro, e com poucos limites obrigatórios criados para assegurar a igualdade substancial dos sujeitos existentes, atribuindo todo o resto ao âmbito de alcance das liberdades individuais, ou seja, do princípio da autodeterminação e da responsabilidade ética de cada um, e evitando, de qualquer modo, a imposição de uma moral etnocêntrica que exceda as escolhas feitas estritamente necessárias à proteção dos bens primários de ordem material indispensáveis para a paz e a segurança dos membros da sociedade (sobre estes aspectos, com definições diversas, R. RORTY, La filosofia dopo la filosofia [1989], trad. it. Roma-Bari 1998; M. WALZER, Sulla tolleranza [1997], trad. it. Roma-Bari 1998; J. HABERMAS-CH. TAYLOR, Multiculturalismo [saggi 1992-96], trad. it. Milano 1998).

\section{O DESENVOLVIMENTO DAS BIOTECNOLOGIAS IMPÕE A CRIAÇÃO DE "NOVOS DIREITOS"?}

A evolução das técnicas biomédicas, desde àquelas relativas à fecundação assistida, até àquelas destinadas à manipulação genética, 
geraram, no campo jurídico, numerosas interrogações: independente das características éticas, se tentou construir, no campo do direito positivo e por operações hermenêuticas complexas, uma série de direitos "novos"; ou seja não integrados entre àqueles expressamente e pontualmente definidos e garantidos pela Constituição de 1948. Assim, por exemplo, o direito à procriação, a ser protegido, mesmo quando comparados com aqueles que, por razões fisiológicas, não poderia ter acesso a reprodução assistida, ou o direito à identidade genética, que tornaria ilícito cada intervenção irreversível sobre o genoma celular, particularmente se relativo à supressão dos traços genéticos peculiares do indivíduo, se poderia fundar na interpretação "aberta" da norma contida no artigo $2^{\circ}$ da Constituição Italiana (segundo a posição assumida por A. BARBERA, sub art. $2^{\circ}$, in Commentario della Costituzione, coordenado por G. BRANCA, Bologna-Roma 1975, 50 ss., e por A. BALDASSARRE, ítem Diritti inviolabili, in Enc. giur. XI, Roma 1989); tal leitura, entretanto, comporta, sob um plano geral, numerosos motivos de perplexidade, postos essencialmente pela potencial criação de antinomias ocultas dentro do sistema definido pela constituição rígida e pelo conseguinte enfraquecimento das garantias da mesma explicitamente previstas (sobre o ponto M. MAZZIOTTI DI CELSO, Lezioni di diritto costituzionale, II ed., II, Milano 1993, 53 ss.; A. PACE, Problematica delle libertà costituzionali, Parte generale, III ed., Padova 2003, 20 ss.). Pareceria preferível, então, pelo menos até que se revele possível, uma colocacão das exigências de tutela dos fenômenos de fato novos dentro das categorias já existentes, mediante uma interpreteção extensiva das normas presentes no texto constitucional: em tal perspectiva o direito à procriação pode ser utilmente entendido como extensão do direito à maternidade (e à paternidade) que se refere o artigo 31 da Constituição Italiana, e aquele da identidade genética como expressão da liberdade pessoal a que se refere o artigo 13 da Constituição Italiana.

Sob a luz de tal reconstrução, pode ser também entendido o critério guia da solução dos numerosos problemas que o fenômeno acima dito implica: se cânone essencial da relação entre autoridade e liberdade no estado laico e pluralista deve ser aquele da máxima expansão possível da esfera da autodeterminação individual, no quadro de uma global função de garantia assumida pelos poderes públicos em relação a todas as instâncias emergentes, atuais ou potenciais (sobre o ponto seria permitido o reenvio a F.RIMOLI, ítem Laicità (dir. const.), in Enc. Giur., XVIII, Roma 1995; ID., Stato laico e integrazione nella prospettiva costituzionale, in Parolechiave, $n^{\circ} 33$ [2005], 207 ss.), uma disciplina positiva da atividade de pesquisa e de aplicação científica no campo em exame, e uma disciplina das mesmas opções possíveis sobre o plano das escolhas individuais atinentes no âmbito da sexualidade e da reprodução biológica, não poderão de qualquer forma afirmar como obrigatório (ou vedado) um determinado comportamento, devendo enquanto possível (ou seja enquanto compatível com a tutela dos bens primários e irrenunciáveis dos sujeitos já existentes) se manter sobre a 
modalidade deôntica do facultativo ou do permitido, consentindo a qualquer indivíduo a mais ampla liberdade de adoção daquelas opções que, antes de tudo sob o plano ético, estes consideram preferíveis; deve portanto valer, também e sobretuto neste campo, o princípio de tolerância que inspira uma sociedade laica e liberal (sobre o ponto U. SCARPELLI, Una bioetica tollerante [1989], in ID., Bioetica laica [raccolta di interventi e saggi], organizado por M. Mori, Milano 1998,19 ss.).

Em outros termos, a intervenção coercitiva do ordenamento aparece particularmente neste contexto, dificilmente tolerável no momento em que vai além dos limites conexos com a necessariedade gerada pela proteção dos direitos primários. Além disso, pelo menos enquanto concerne o perfil da atividade científica, este deve ser ulteriormente garantido a partir da liberdade do art. 33, parágrafo $1^{\circ}$ da Carta, onde a tutela da investigação e todavia por considerar valor primário do ordenamento, e do direito à saúde nos termos do artigo 32 da mesma, se devendo individualizar na perspectiva do progresso das técnicas biogenéticas um instrumento com potencial de forte melhoramento das condições sanitárias da coletividade, em particular no que concerne à eliminação das doenças hereditárias. Naturalmente, o emprego das técnicas em questão deverá ser orientado a fim de eliminar as patologias, em relação a um parâmetro de "normalidade" ainda controverso mas estatisticamente médio: o perigo de utilização "eugênicas" das manipulações biológicas obviamente existe, mas não pode razoavelmente induzir à tentativa de frear ou impedir a pesquisa, que seria entre outras coisas um estímulo, de uma legislação mais rígida à emigração em direção a países mais tolerantes (em uma dimensão de globalização que resulta, de qualquer forma, impossível qualquer forma de controle real) ou ainda à clandestinidade. Em ambos os casos os efeitos produzidos seriam, além de imprevisíveis, também incontroláveis, e assim o remédio seria muito pior do que o mal temido (sobre o ponto L. NIELSEN, Dalla bioetica alla biolegislazione, VÁRIOS AUTORES, Una norma giuridica per la bioetica, coordenado por C.M. MAZZONI, Bologna 1998, 45 e ss., e ainda L. CHIEFFI, Ricerca scientifica e tutela della persona. Bioetica e garanzie costituzionali, Napoli 1993, spec. 243 ss.).

Contudo, o aperfeiçoamento e a difusão de tais técnicas deve ser controlada de várias formas, não tanto porque resguarda a possibilidade de acesso ao uso das mesmas por parte dos indivíduos, mas sim para proteger a privacidade nos confrontos de um concreto risco de manipulação dos dados sensíveis inerentes à indentidade genética por parte dos poderes públicos, mas também por parte de algumas organizações privadas que prestam serviços essenciais. A tal propósito as garantias já previstas na Lei $n^{\circ} 675 / 1996$ sobre a tutela dos dados pessoais, e agora pelo recente decreto legislativo de 30 de junho de 2003, no 196 sobre o tratamento dos dados sensíveis por parte de agentes públicos e privados, deveriam ser corretamente aplicados, e eventualmente reforçados: a hipótese de 
"arquivamentos" dos cidadãos com base na genética, mas ainda mais de exclusão e marginalização dos indivíduos cuja reduzida expectativa de vida seja derivada de exames clínicos verificados, e levado ao conhecimento de fornecedores de alguns bens ou serviços (pense-se nas várias formas de seguro de vida ou saúde, mas também na possibilidade concreta de ser utilizada para o desenvolvimento de determinadas atividades laborais), e mais do que plausível, incidiria rapidamente sobre a igualdade real entre os cidadãos, criando subitamente categorias diferenciadas entre os mesmos.

\section{A INTERVENÇÃO LEGISLATIVA: PROBLEMAS GERAIS}

Por muitos anos permaneceu, e em parte ainda existe, na Itália, uma aparente lacuna normativa em matéria de bioética: a ausência de uma disciplina pontual permitiu, principalmente junto às estruturas privadas de assistência clínica, uma consistente expansão da utilização das técnicas de fecundação artificial. Em outros países europeus, uma disciplina foi anterior: assim, por exemplo, foi na Espanha com a lei de 22 de novembro de $1988, n^{\circ} 35$ (modificada pela lei de 21 de novembro de 2003, $n^{\circ} 45$ sobre a pesquisa com embriões); pelas três Lois de Bioethique francesas, $n^{0 \mathrm{~s}} 458$, 653 e 654, todas de 29 de julho de 1994, respectivamente para o tratamento dos nomes dos doadores para fins de pesquisa, pelo corpo humano e pela doação, emprego de elementos e produtos do corpo humano, e ainda para a assistência médica à procriação e ao acompanhamento pré-natal; pela Inglaterra com o Surrogacy Arrangement Act de 1985, sobre a maternidade de aluguel, ou o Human Fertilization and Embriology Act de 1990, sobre a procriação assistida; pela Alemanha com o Embryonenschutzgesetz de 13 de dezembro de 1990; pela Áustria com a lei de 14 de maio de 1992, $n^{\circ} 275$, também sobre a procriação assistida. Na Itália, mais do que em outros lugares, muito pesadas sempre foram as objeções feitas por parte dos Católicos, particularmente sobre o problema da destruição dos embriões (tout court equiparados a pessoas, ou seja sujeitos de direito e vítimas de um homicídio, segundo uma concepção sagrada da vida, que entretanto se funda numa tão incerta definição do momento inicial da mesma; sobre estes aspectos, no meio de uma literatura vastíssima, M. MORI, La fecondazione artificiale. Una nuova forma di riproduzione umana, Roma-Bari 1995, 54 ss.; e ID., La fecondazione artificiale umana: questioni morali nell'esperienza giuridica, Milano 1988; para uma leitura de inspiração católica F. SANTOSUOSSO, La fecondazione artificiale umana, Milano 1984, mas especialmente E. SGRECCIA, Manuale di bioetica, III ed., 2 voll., Milano 2000-02), além disso as consequências sobre as relações entre os componentes do casal (assim, segundo um velho problema enfrentado pelo juiz criminal, a inseminação heteróloga - ou seja, aquela efetuada com sêmen de doador externo ao casal - poderia integrar os extremos do adultério: sobre o ponto veja-se a decisão do Tribunal de Padova, de 16 de fevereiro de 1959, em Foro it., 1959, II, 88 ss.). Mais relevantes, e mais recentemente enfrentados pela jurisprudência constitucional, são as 
características inerentes à relação entre os genitores e os filhos nascidos com métodos artificiais: assim a possibilidade do desconhecimento sucessivo do filho por parte do pai que anteriormente tivesse consentido na inseminação heteróloga da mulher, por muitos anos causa de discussões em decisões de mérito (veja-se, entre as primeiras, o julgado do Tribunal de Roma, de 30 de abril de 1956, em Giur.it., 1957, I, sez. II, 225 ss.) foi objeto da decisão no 347/1998 da Corte Constitucional (em Giur. cost., 1998, 2632 ss., com observações de E. LAMARQUE), que enfrentando pela primeira vez os problemas inerentes à fecundação assistida e afastando-se, sobre o ponto, da orientação oposta prevalente na jurisprudência ordinária (pela qual se veja, ao contrário, as decisões dos Tribunais de Cremona de 17 de fevereiro de 1994, em Giur. it., 1994, I, 2, 996, e de App. Brescia, de 14 de junho de 1997, ibidem, 1997, I, 2, 48, que negam também qualquer tutela ressarcitória), corretamente excluiu, sobre a base do interesse preeminente do menor, a aplicabilidade da ação de desconhecimento do art. 235 c.c. no caso em questão, circunscrevendo-a somente às hipóteses de adultério, entre os quais não se inclui qualquer hipótese de inseminação heteróloga. Sobre tal decisão da Corte Constitucional, que todavia não ataca o mérito sobre a legitimidade de tal tipo de inseminação, esperando mesmo uma intervenção legislativa sobre a matéria, segue a decisão de Cassação, Seção I, de 16 de março de 1999, nº 2315 (em Gazz. Giur., 1999, n 14-15, IV, 64), e aquela do Tribunal de Napoli de 24 de junho de 1999 (em Dir. e fam., 2000, 185 ss.), que adotam a posição excluindo a oponibilidade da ação de desconhecimento do art. 235 c.c. seja em consideração dos ideais de lealdade, boa fé e correção que, no quadro da relação familiar, seriam violados pelo marido que, de início consente, e resolve, em seguida, refutar a própria paternidade jurídica, seja pela clara lesão dos interesses dos menores e por alusão aos preceitos dos arts. 2, 30 e 31 da Constituição Italiana.

Todavia, as características problemáticas relativas às técnicas, continuamente renovadas, de fecundação artificial, são numerosas, e sempre suscitaram, pelas suas inegáveis implicações éticas, debates fortes entre as forças laicas e aquelas católicas, de modo a impedirem, de fato, por muitos anos, a aprovação de uma disciplina completa, da definição de licitude dos métodos singulares (fecundação in vivo e in vitro, nas numerosas variantes), aos mais inquietantes fenômenos das surrogate mothers (assim ditos "úteros de aluguel": os contratos de mães de aluguel são considerados nulos na Itália por falta de requisitos de possibilidade e licitude com base nos arts. 1418 e 1346 c.c. Mas, em outro contexto, veja-se o caso "Baby M.", decidido pela Corte Superior de Nova Jérsei em 31 de março de 1987 em uma decisão que fez barulho, reportada em Foro it., 1988, n 4, 97 ss., com observações de G. PONZANELLI, e pela Corte Suprema do mesmo Estado em 3 de fevereiro de 1988, com decisão reportada ibidem, 1989, n 4, 293 ss., com observações de G. PONZANELLI e R. CLARIZIA; na Itália 
além da decisão do Tribunal de Monza, de 27 de outubro de 1989, em Foro it., 1990, n ${ }^{\circ} 1,298$ ss, veja-se a decisão do Tribunal de Roma, de 17 de fevereiro de 2000, em Giur. mérito, 2000, 527 ss., com observações de A.G. CIANCI), até às possibilidades de fecundação com o sêmen congelado de um componente do casal falecido, os traços ideológicos, morais e jurídicos (particularmente sob o plano civilista) ligados a tal contexto - mas inevitável - o desenvolvimento biotecnológico incide diretamente sobre os cânones da psicologia coletiva. Isso explicava a proteção, que se tornou comum, de uma intervenção pontual dos legisladores, para colmatar uma lacuna do ordenamento italiano que havia sido esporadicamente enfrentada somente por circulares ministeriais (assim uma Carta-Circular do Ministro da Saúde Degan de $1^{\circ}$ de março de 1985, endereçada às Regiões e intitulada "Limiti e condizioni di legittimità dei servizi per l'inseminazione artificiale nell'ambito del Servizio Sanitario Nazionale", autorizava junto aos centros públicos somente a inseminação homóloga, deixando aos privados substancial liberdade de ação, esta foi depois integrada por uma outra Circular do Ministro Donat-Cattin de 27 de abril de 1987, e por uma ordem ministerial de 5 de março de 1997, institutiva do Registro nacional italiano da procriação médico-assistida, no qual todos os centros privados que operam no setor devem fornecer dados sobre a atividade desenvolvida).

A XIV legislatura assinalou todavia uma direção: a nítida afirmação das forças conservadoras do centro direita permitiu (embora com significativa contribuição das forças católicas de oposição, e com o também significativo distanciamento dos liberais da maioria do governo, isto que evidenciou a verdadeira censura ideológica atual, articulada segundo a distinção laicos/ católicos mais que segundo a tradicional alternativa entre esquerda e direita), a aprovação da lei de 19 de fevereiro de 2004, no 40, que dita "Normas em matéria de procriação medicalmente assistida", disciplinando o setor segundo uma posição decididamente orientada sobre o plano ideológico, e consentindo o recurso à procriação assistida somente "quando não existirem outros métodos terapêuticos eficazes para remover as causas de esterilidade ou infertilidade", cuja "solução" a inteira disciplina é prevista (art. ${ }^{\circ}$ ). Além de tal nítida delimitação do escopo, que se traduz na necessidade de exibição de declarações médicas que atestem casos de "esterilidade ou infertilidade inexplicáveis" para acessar a tais técnicas, se proíbe a inseminação heteróloga (art. $4^{\circ}$, parágrafo $3^{\circ}$ ), e se autoriza o acesso somente a "casais maiores de idade e de sexo diverso, casados ou conviventes, em idade potencialmente fértil, ambos vivos" (art. $5^{\circ}$ ), que deverão de qualquer forma apresentar um "consenso informado" (art. 6 ${ }^{\circ}$ ). Obviamente, a lei reconhece aos nascidos mediante tais técnicas o status de filhos legítimos ou reconhecidos pelo casal, impedindo, todavia, a ação de desconhecimento de paternidade do art. $235,1^{\circ}$ parágrafo, c.c., e não a impugnação do art. 236 c.c., mesmo em caso de inseminação heteróloga feita em violação à lei, com a condição de que resultam de atos conclusivos do consenso do cônjuge ou convivente; 
em tal caso porém o doador não adquire qualquer relação jurídica com o nascido (art. $9^{\circ}$ ). As intervenções de procriação médico-assistida podem ser efetuadas seja em estruturas públicas quanto em estruturas privadas autorizadas pelas regiões e inscritas em um cadastro nacional junto ao Instituto Superior de Saúde, de acordo com os requisitos técnico-científicos e organizacionais determinados por cada Região e pelas Províncias autônomas (o que produzirá desigualdades óbvias de condições entre as diferentes áreas geográficas). Além das sanções previstas pelo art. 12 da lei de violação das proibições mencionadas, uma ulterior disciplina é fornecida pelo capítulo VI (art. 13 ss.) para a "tutela do embrião": se proíbe "qualquer experimento sobre algum embrião humano", e a pesquisa com embriões é autorizada somente para "finalidades terapêuticas ou diagnósticas que sejam relativas à tutela da saúde e ao desenvolvimento do mesmo embrião, e enquanto não sejam disponíveis métodos alternativos"; são, ainda, proibidos a produção de embriões com fins experimentais, a seleção ou a manipulação em cada procedimento artificial com fundo eugenético, a clonagem nas suas várias formas, a fecundação de gametas humanos com gametas de outras espécies para a produção de híbridos ou quimeras (art. 13). As normas mais discutidas advêm, todavia, do art. 14, que proíbe a crioconservação e a supressão de embriões (sem prejuízo do disposto na Lei no 194/1978, sobre a interrupção voluntária da gravidez, mas admite a criopreservação de gametas), dispondo que as técnicas em questão "não devem criar um número de embriões superior àquele necessário a uma única $\mathrm{e}$ contemporânea implantação, no entanto, não superior a três"; se revelar-se impossível tal implantação por força maior é permitida uma crioconservação enquanto não seja possível a transferência ao útero, "a ser realizada assim que possível"; é proibida porém a "redução embrionária de gravidez múltipla". Os aspirantes a genitores, portanto, poderiam satisfazer o próprio desejo além da expectativa, com um agradável parto de trigêmeos, podendo no entanto ser informados sobre o número e, "sob sua requisição", sob o estado de saúde dos embriões produzidos e por transferir ao útero, com vistas à preparação adequada ao evento (cuja dimensão será de qualquer forma inevitável, dadas as mencionadas proibições). Toda a lei é assistida por um severo aparato sancionatório, sobretudo em relação ao pessoal das estruturas sanitárias, a qual se reconhece, no entanto, o direito à objeção de consciência (artigo 16). Assim, com escolha fortemente condicionada pelas pressões das forças católicas, prevalentes na Comissão nacional de bioética e transversalmente dispostas no Parlamento, as soluções trazidas pela lei, mesmo que um tanto temperadas em sede atuante pelas "linhas guia" ministeriais (emanadas com base no art. $7^{\circ}$ da lei e não livres de incongruências em relação a esta), particularmente para a disciplina de implantação de embriões, se põem no quadro de orientação já restritiva (semelhante àquele que inspira o citado Embryonenschutzgesetz vigente na República Federal alemã, legível em Medicina e morale, 1991, n 3 , 509 ss.), e não parecem de modo algum responder as exigências reais do 
fenômeno evolutivo, nem, tampouco, a uma correta aplicação dos princípios de uma democracia pluralista e de um Estado laico. Tal forma de proibição (certamente compartilhada em relação às proibições de manipulação eugênica, mas muito menos para o problema da proteção do embrião, e absolutamente inaceitável para as limitações relativas à fecundação heteróloga e à coerção da liberdade de escolha do processo de procriação, e para inibir a investigação em células estaminais embrionárias) inibe fortemente a autodeterminação individual sem todavia conseguir, razoavelmente, impedir as possíveis degenerações que um certo empenho da pesquisa biogenética, desenvolvida em sede experimental ou em aplicações concretas, pode conduzir, sem dúvida. A escolha de recorrer à fecundação assistida não deveria ser de algum modo subordinada à condição de atestada impossibilidade de procriação natural, devendo ser principalmente remetida à liberdade de determinação do casal. Também a proibição de inseminação heteróloga (que a este ponto, com equívoco semântico, é só aquela relativa ao uso de um sêmen de doador anônimo e ainda estranho ao casal, ainda que de fato, por esta última se prescinde da relação conjugal), no momento em que sejam, sob o plano normativo, resolvidos preliminarmente os problemas legados à ausência de adultério e às possibilidades de consequente desconhecimento do filho nascido da mesma com o consenso do componente masculino do casal, exprime, sobretudo, uma atitude marcadamente ideológica e intolerante, nada de acordo com o espírito de uma ética pluralista, e pode ulteriormente impedir o emprego de tal técnica (que poderia ser, por exemplo, justificada pela probabilidade de doenças hereditárias ligadas ao emprego do sêmem homólogo), também onde seja a única possível para garantir um exercício efetivo do direito à maternidade-paternidade, que é assim garantido pelo art. 31 da Constituição Italiana (e que deveria outrossim, poder ser exercido livremente, sem constrições ideológicas); além disso, a nova lei deixa não resolvidos problemas de difícil solução (um entre todos: que fim se dará aos numerosos embriões já congelados nos laboratórios?). Tal lei, entretanto, afetada por sérias dúvidas de constitucionalidade (sobre o ponto C. TRIPODINA, Studio sui possibili profili di inconstituzionalità della legge $n^{\circ}$ 40/2004 recante "Norme in materia di procreazione medicalmente assistita", em Dir. pubbl., 2004, $n^{\circ} 2$ 2, 501 ss.; P. VERONESI, La legge sulla procreazione assistita alla prova dei giuridici e della Corte costituzionale, em Quad. cost., 2004, $\mathrm{n}^{\circ}$ 3, 523 ss.; F. MEOLA, La scelta di procreare tra (poche) libertà e (molti) limiti: considerazione a margine alla recente legge sulla procreazione medicalmente assistita, em Progressi biomedici tra pluralismo etico e regole giuridiche, coordenado por R. PRODOMO, Torino 2004, 117 Ss., e também as múltiplas intervenções em www.laprocreazioneassistita.it) no entanto permaneceu intacta mesmo depois do referendum abrogativo, realizado em 12 e 13 de junho de 2005 relativo aos principais pontos da lei, onde não foi alcançado o quorum de validade, após uma campanha abstensionista de forte impacto, implementada pelas forças católicas com a penetrante 
presença da Igreja (toda a situação foi reconstruída no volume de Vários Autores, I referendum sulla fecondazione assistita, coordenado por M. AINIS, Milano 2005). Em realidade, como dito, as possíveis distorções, individuais e sociais, que poderiam derivar de um emprego instrumental de certas técnicas com fins considerados pouco edificantes, ou por motivos opináveis a um juízo moral externo, não podem de algum modo induzir a ultrapassar o nível da avaliação ética individual, seja do sujeito agente seja dos seus "vizinhos"; uma ética pública imposta autoritariamente com uma lei repugnante para cada ordenamento liberal, e funda-se também sobre opções e avaliações que, lidas com perspectiva mais ampla, demonstram toda a sua subjetividade. Assim, por exemplo, a proibição, comum a muitas legislações, da "maternidade de aluguel" (não expressamente prevista, mas agora implicitamente evidente na Lei $n^{\circ}$ 40/2004) funda-se sobre certos problemas jurídicos que podem derivar (e que poderiam ser, porém, facilmente resolvidos na via normativa), mas, sobretudo, sobre grau de depreciação que evoca, em alguns, a ideia que uma mulher possa escolher de fazer-se substituir na gravidez para não perder, por exemplo, oportunidade de carreira. Mas, além do fato que tal tipo de juízo não deveria caber aos legisladores, consistindo no exercício de uma liberdade individual, seria enfim mais deplorável, segundo uma ética da responsabilidade, a mãe que agisse de tal modo, talvez para assegurar um futuro mais confortável para o próprio filho, ou mesmo aquela que, já mãe de outros filhos, se recusa a interromper a própria nova gravidez para tratar um câncer que lhe levará à morte certa, com o resultado de abandonar o novo filho, parido in extremis, e os seus irmãos para um destino de órfãos? As hierarquias católicas rejeitaram a primeira e beatificaram a segunda: mas a dúvida é mais que legítima, e demonstra a insustentabilidade, particularmente nesse âmbito, de uma moral comum que não seja fruto de uma prevaricação cultural; o momento da procriação se reveste de aspectos profundos da existência individual, e uma intervenção direta dos poderes públicos no ato de escolha, ou seja, do ano e do modo de exercício de tal faculdade humana constitui-se uma das intrusões mais odiosas na relação entre autoridade e liberdade. Em tal sentido a experiência dos Comitês de ética, ainda presentes em muitas estruturas sanitárias, pode contribuir certamente para aliviar o peso psicológico das escolhas individuais, mas não pode ainda constituir um ponto de referência obrigatório para as mesmas; o que pode revelar-se útil, é, porém, um papel informativo de todas as organizações, institucionais ou não, para atingir aquele nível de "consenso informado" que resta absolutamente necessário em cada prática sanitária (sobre o tema A.G. SPAGNOLO, Comitati di bioetica in tema di procreazione artificiale, in Medicina e morale, 1993, $\mathrm{n}^{\circ}$ 1, 205 ss., sobre consenso informado H.T. ENGELHARDT Jr., op. cit., 300 ss; L. CHIEFFI, op. cit., 191 ss., E. LECALDANO, Bioetica. Le scelte morali, Roma-Bari 1999, 29 ss., 177 ss e 297 ss.) 
4 BIOÉTICA, DIREITO E VIDA HUMANA: OS PROBLEMAS DO INÍCIO E DO FIM DA EXISTÊNCIA INDIVIDUAL

\subsection{As Técnicas para a Fecundação Assistida e o Direito à} Procriação

Os problemas conexos, em sentido amplo, da bioética são todavia mais complexos do que aqueles estritamente relativos à fase procriativa, e investem enfim as experiências primárias e mais profundas da existência humana: do nascimento até a morte, os perfis que o debate enfrenta são aqueles tradicionalmente próprios da reflexão do homem sobre sua própria condição, que a expansão das possibilidades técnicas de intervenção na origem da vida acabou por torná-la ainda mais enigmática.

Assim as características de oportunidade de uma disciplina legislativa específica emergiram, de forma muito problemática, seja pelo já mencionado fenômeno da procriação assistida, seja pela licitude ética e jurídica da manipulação genética, experiência bem comentada na Itália e, seja ainda, pelo delicadíssimo fenômeno da eutanásia. Nos primeiros dois casos, deve essencialmente, como se diz, o assunto fundamental sobre a disponibilidade da vida por parte dos genitores, onde se adere a uma imposição religiosa do tipo escatológica, a doação da própria vida se põe como ato irreversível, sendo o nascituro potencialmente destinado a uma existência eterna e sendo, por consequência, incongruente cada consideração sobre oportunidade da própria vida na sua dimensão terrena, sobre sua duração e sua "qualidade". Parando-se na leitura católica, nascer significa, no entanto, poder aderir à graça; a vida, enquanto dom divino, não se volta para a disponibilidade do indivíduo (nem de seus genitores), e toda forma de existência concreta é, por si, digna de ser vivida, daí a frenética (e provavelmente inútil) pesquisa do momento no qual, biologicamente, a vida se gera, legada ao reconhecimento do embrião (ou o óvulo fecundado pelo encontro de dois gametas) de um estado em tudo similar àquele de ser já nascido, com a consequente obrigação de tutela dos seus direitos primários, e antes de tudo daquele à vida (uma consideração das diversas técnicas sobre estas características em M. MORI, op. cit., 25 ss. e 85 ss.; E. LECALDANO, op. cit., 133 ss., um panorama das técnicas em N. GARCEA, Tecniche di procreazione assistita, in Medicina e morale, 1993, $\mathrm{n}^{\circ}$ 1, 59 ss., e em C. FLAMIGNI, I laboratori della felicità. La cura della sterilità tra successi e delusioni, Milano 1994: mas se trata obviamente de um setor em contínua evolução). Removida a hipótese, todavia, as consequências se tornam inaceitáveis: por uma ética laica, que se põe como ética da dúvida, a ideia da sobrevivência depois da morte é nada mais do que uma hipótese, e não consegue justificar as escolhas concretas: em tal perspectiva, os pais que decidem procriar impõem, ipso facto, a vida (e os prováveis sofrimentos, e ainda, a certa, futura morte biológica) de um sujeito que não existe e não pode de qualquer forma, obviamente, exprimir o próprio consenso com uma escolha que lhe envolve imediatamente e totalmente. Diante de tal forma - inevitável - de prevaricação, 
a ideia de um direito qualquer do sujeito futuro revela toda a sua inconsistência: essa se funda enfim sobre uma presunção de aceitação da vida que é e permanece própria dos sujeitos existentes, mas não pode ser de nenhum modo verificada no nascituro. A responsabilidade pela escolha, isto é, se põe inteiramente na esfera dos genitores, e eventual decisão de interromper uma gravidez, ou de recorrer a técnicas de procriação mais avançadas para os fins particulares, não pode de nenhum modo, no panorama de uma ética tal, ser considerada ilegal, ou mais prevaricatória sobre a (hipotética e não avaliável) vontade do nascituro de quanto não seja a própria decisão de procriar (sobre o tema E. RIMOLI, Appunti, cit., spec. 486 ss.; E. LECALDANO, op. cit., 168 ss.).

$\mathrm{E}$, portanto, em um ordenamento que deve tutelar, até que possível, todas as instâncias existentes, a imposição de uma concepção particular, especialmente nestas matérias, deve como dito considerar-se intolerável: a determinação do momento no qual o ser vivo se torna sujeito de direito, adquirindo a capacidade jurídica e portanto a idoneidade de ser centro de imputação de direitos, constitui o fruto de uma escolha do próprio ordenamento, de uma qualificação que deve ter em conta múltiplos fatores. A solução aceita pelo art. $1^{\circ}$ c.c. que estabelece a aquisição da capacidade jurídica no momento do nascimento (e prescindindo dos casos particulares de direitos a favor do concebido, cujo reconhecimento é também subordinado, pelo mesmo art. $1^{\circ}, 2^{\circ}$ parágrafo, c.c., no evento do nascimento; veja-se os arts. 462 e 784 c.c., sobre a capacidade do concebido - e igualmente dos não ainda concebido - a suceder e a receber doações) representa ainda um ponto de referência que, pela sua objetividade, se demonstra capaz de manter um nível satisfatório de consenso comum; por isso que protege a licitude do aborto, a lei de 22 de maio de 1978, $\mathrm{n}^{\circ}$ 194, pondo em relevo o art. $1^{\circ}$, juntamente com a defesa da vida humana desde seu início, o direito a uma procriação "consciente e responsável", cumpre uma ponderação entre os valores conflitantes da liberdade de autodeterminação dos genitores e do (presumido) interesse à existência do nascituro, que aparece como uma correta atuação da norma sobre a tutela da maternidade conforme art. 31 da Constituição Italiana (sobre o ponto E. RIMOLI, op. ult. cit., 542 ss., sobre o aborto terapêutico antes da lei de 1978, veja-se também a decisão no 27/1975 da Corte Constitucional, em Giur. cost., 1973, 117 ss.; ainda a decisão n 35/1997, ibidem, 1997, 281 ss., com observações de C. CASINI e M. OLIVETTI, que, mesmo falando de fundamento constitucional da tutela do concebido, não parece adicionar novos detalhes, porque reconhece a necessidade de um balanciamento de tal tutela com os direitos da mãe, que já é operado pela lei). E, no entanto, algumas novas características continuam a serem postas, porque as práticas biogenéticas mais avançadas levantam novas questões também no que diz respeito aos princípios constitucionais, assim, por exemplo, pode-se dizer que existe um direito do nascituro a um patrimônio genético não manipulado, e um consequente 
limite às intervenções sobre o genoma? Ou melhor, existe um direito à saúde do próprio nascituro que exige este tipo de intervenções onde seja possível, e através destas, eliminar defeitos genéticos e doenças hereditárias?

E enfim, nesta última hipótese, poderia no futuro o filho ressarcir-se dos genitores que, enquanto sabedores da possibilidade de benefício com a intervenção biogenética, e não tenham recorrido às técnicas apropriadas mantendo sobre o próprio filho o risco (ou a certeza) das sucessivas doenças, produzindo, assim, um "dano na procriação"? Diante dessas hipóteses, todavia, se demonstra ainda uma certa insustentabilidade da construção fundada no sujeito futuro; a tutela da saúde do nascituro deve reentrar na responsabilidade individual dos genitores, mas não pode ser autoritariamente imposta como obrigação gerada pelo direito em primeiro lugar, e as obrigações de assistência e manutenção impostas pelo art. 29 da Constituição Italiana e pela lei ordinária deverão surgir e serem adimplidas pelo momento do nascimento do menor (sobre dano na procriação, característica muito interessante nessa perspectiva, veja-se a jurisprudência americana citada por H.T. ENGELHARDT Jr., op. cit., 254 ss.; para a doutrina italiana, leia-se V. ZENO-ZENCOVICH, La responsabilità per procreazione, em Giur. it., 1986, IV, 113 ss.). Por outro lado, racionalizando o contrário, deveria ser imposta como obrigatórias (pela lei, com base no $3^{\circ}$ parágrafo do art. 32 da Constituição Italiana) também os tratamentos de saúde psicológica e fisiologicamente gravosos, destinados ao exame do estado de saúde do feto (pense-se no exame de amniocentese para as gestantes em idade avançada), com a conseguinte privação da faculdade de escolha dos únicos titulares existentes de um direito - aquele à procriação, derivado do art. 31 da Constituição Italiana - que se põe como único elemento certo e fundante para toda a atividade reprodutiva. Vendo bem, de fato, só reconstruindo por inteiro os problemas aqui tratados à luz de uma expectativa de direito relativa aos genitores, enquanto sujeitos existentes e responsáveis, é possível reunir soluções coerentes com os assuntos de fundo do modelo de democracia pluralista. O direito de ter filhos, recorrendo às técnicas mais adequadas, em cada caso singular em um determinado momento, permitidas pelo desenvolvimento científico e o direito de ser capaz de controlar, também quando possível, o estado fisiológico futuro do nascituro com intervenções que visam eliminar as dificuldades previsíveis decorrentes da única configuração genética, permitiriam, por um lado, o prosseguimento correto do princípio básico da expansão das liberdades individuais e das responsabilidades do exercício, permitindo que cada um siga sua própria orientação ética na coexistência de muitas culturas diferentes e, por outro, evitar o abuso de poder inerente aos fundamentalismos de vários tipos, que não hesitam em usar as ferramentas obsoletas da lei natural, os direitos de sujeitos não existentes, devidamente configurados, como meios de persuasão para impor autoritariamente a sua própria concepção de mundo e, finalmente, a sua supremacia. Quase antítese a esta abordagem é, no entanto, como 
mencionado, a opção feita pelo legislador com a Lei 40/2004 (v.supra, par. 3), que limita severamente seja as opções de acesso às técnicas de procriações assistidas, seja a pesquisa com embriões: que, além de criar conflitos óbvios com a Constituição, se revelará bem cedo escolha em tudo incongruente no plano prático: porque técnicas mais avançadas de fecundação acabarão por ser praticáveis, com restrições bem menores, apenas em outros países, favorecendo assim os sujeitos mais ricos que são capazes de suportar os custos de uma transferência, ou, pior, recorrerão à clandestinidade mais incontrolável, segundo a experiência de conhecidos procedimentos abortivos. Com relação à pesquisa biogenética e biomédica, uma função de controle das possíveis degenerações que transcendem em uma série de proibições ideológicas acabará, na melhor das hipóteses, por isolar ainda mais a Itália dos progressos científicos, incentivando o constante êxodo dos melhores investigadores e não impedindo, mesmo aqui, as possíveis atividades clandestinas, com as consequências mais imprevisíveis. Assim, seria mais adequado restringir a ratificação, aprovada pela lei de 28 de março de 2001, $n^{\circ} 145$, da Convenção estabelecida em Oviedo em 4 de abril de 1997 dos Estados-Membros do Conselho da Europa (com o relativo Protocolo adicional de 12 de janeiro de 1998, $\mathrm{n}^{\circ}$ 168), que proibindo a experimentação sobre o genoma com fins eugênicos, impede a simples criação de embriões humanos para fins de pesquisa, consentindo-a (com "adequada proteção") sobre embriões in vitro (art. 18), e proibindo ainda a clonagem de seres humanos, vivos ou mortos (art. $1^{\circ}$ do Protocolo adicional), para, em qualquer caso, respeitar um "mínimo ético" também compartilhado pela abordagem laica.

Inclusive o Tratado que institui uma Constituição para a Europa, assinado pelos países da União Européia, em Roma, em 29 de outubro de 2004 e ainda em processo de ratificação (apesar do fracasso do referendo na França e na Holanda, o que provavelmente levará a sua revisão), fixa alguns princípios na matéria: assim o art. II-63, sobre direito à integridade da pessoa, requer o consenso livre e informado para os tratamentos de saúde, proibindo ainda as práticas eugênicas, o uso do corpo humano ou de suas partes com fins lucrativos, e a clonagem reprodutiva de seres humanos. Todavia, mesmo a Conferência Geral da UNESCO também aprovou, em 10 de outubro de 2005, uma Declaração Universal sobre Bioética e Direitos Humanos, na qual, embora sem entrar no mérito de técnicas individuais, reiteram-se alguns princípios basilares para a garantia do pluralismo ético na pesquisa biomédica, como o respeito pela dignidade humana, o direito à confidencialidade e à privacidade, e aqueles a não estigmatização e a não discriminação, a que se une um princípio de responsabilidade social da pesquisa e a tentativa de deixar homogênea as disciplinas dos 197 países aderentes, com o fim de permitir a todos os cidadãos, em uma dimensão globalizada, o acesso aos medicamentos e às técnicas mais evoluídas, antepondo assim o interesse dos indivíduos sobre quaisquer outros e 
deixando aos Estados a tarefa de hamonizar uma base ética comum com as tradições e exigências locais (a Declaração, fruto de dois anos de trabalho do Comitê Internacional de Bioética, segue a Declaração sobre o Genoma Humano e os Direitos do Homem, de 1997, aprovada em 1998 pela Assembléia Geral da ONU, e a Declaração Internacional sobre dados genéticos humanos, de 2003, na qual se determinam princípios relativos à colheita, armazenagem, tratamento de dados genéticos humanos). Além de qualquer (talvez inevitáveis) elemento utópico, típico de cada tentativa de universalização dos direitos, a intenção de fundo aparece certamente aceitável, orientada a uma superação das desigualdades do planeta que, aqui mais do que em outros lugares, estão entre os resultados menos toleráveis dos processos de globalização.

\subsection{A Eutanásia e o Direito de Morrer}

Um outro, e talvez mais delicado, problema se põe diante do final da vida biológica, e das decisões que se impõem a um doente em fase terminal, seja sobre o perfil terapêutico que sobre o aspecto ético legado à escolha do prosseguimento de uma vida que se tornou, sob o plano qualitativo, sempre mais difícil de sustentar. Põe-se aqui o dilema da eutanásia, entendida no sentido passivo como suspensão dos tratamentos ou dos meios técnicos de sobrevivência (cardioestimuladores, respiradores mecânicos), ou ainda em sentido ativo, como ação direta para antecipar a morte do paciente com a finalidade de diminuir sofrimentos inúteis causadas por uma doença irreversivelmente fatal (sobre eutanásia H.T. ENGELHARDT Jr., op. cit., 343 ss.; J. RACHELS, La fine della vita. La moralità dell'eutanasia. [1986], trad. It. Torino 1989; H. KUHSE, The sanctity of life doctrine in medicine. A critique, Oxford 1987; H. JONAS, II diritto di morire [1978], trad. It. Genova 1991, especialmente 45 ss., P. SINGER, op. cit., 131 ss.; bem como as breves, mas intensas intervenções de U. SCARPELLI, ora in Id., Bioetica laica, cit., 123 ss., I. KENNEDY, Il diritto di morire, em AA.VV., Una norma giuridica, cit. 217 ss.; E. LECALDANO, op. cit., 49 ss.; P. BORSELLINO, Decisione di fine vita tra morale e diritto, em Progressi biomedici, cit., 185 ss.; P. GIUSTINIANI, Uscita consapevole dalla vita e desiderio di esistere per sempre. Prospettive filosofiche per una bioetica di fine vita, ibidem, 199 ss.). Se no primeiro caso a intervenção se pode dizer, embora não sem alguma dúvida fundada, legítima, onde seja acertada a impossibilidade da melhora das condições do sujeito, no segundo, obviamente, a contiguidade de um comportamento deste gênero com o homicídio (ou com o suicídio) é bastante evidente: os principais motivos que, sob o plano moral, podem induzir o sujeito a agir, embora fundando-se no consenso do doente, são todavia, insuficientes para constituir excludentes da responsabilidade penal (a propósito se veja o art. 579 c.p., sobre homicídio do consenciente). Por outro lado, também neste caso, o consenso consciente do paciente, que deve ser considerado, no entanto, essencial, poderia não ser obtido em concreto, pelas mesmas condições extremas das quais estas trata. E, todavia, o problema não é assim 
facilmente resolvido, pelo menos sob o plano ético que deveria preceder a opção jurídica; é óbvio que cada escolha no sentido de legitimação da eutanásia (segundo orientações inclusive tentadas em outros países: o exemplo holandês, com a Lei $n^{\circ} 137 / 2007$, que dita normas sobre 0 suicídio assistido, é o mais significativo), comportaria riscos notáveis de degeneração, expondo o paciente a tentativas de escravização, fundados no estado depressivo comum dos doentes em fase terminal, e favorecidos pelo interesse à retirada dos órgãos saudáveis (sobre o ponto se veja, todavia, a recente lei de $1^{\circ}$ de abril de 1999, n 91 , sobre a doação de órgãos; sobre o problema da doação e do comércio de órgãos, atualmente vivíssimo, H. HANSMANN, Mercati di organi umani, em AA.VV, Una norma, cit., 177 ss.; e C.M. MAZZONI, Etica del dono e donazione di organi, ibidem, 207 ss.; O problema da comercialização é tratado por E. BERNAT, Verso la commercializzazione di organi umani?, Ibidem, 193 ss.). Além disso, para além de tais deploráveis - mas não improváveis - hipóteses, há a considerar que cada forma de renúncia à vida, não motivada por razões existenciais mas somente pela desconfiança nas concretas possibilidades de recuperação de um nível qualitativo aceitável, implica também a exclusão de cada enquanto possível - vantagem no futuro derivada da aquisição de novas técnicas clínicas. Não obstante, pelo menos onde seja possível verificar a vontade do doente, e onde haja uma razoável certeza da impossibilidade de melhoria das condições do mesmo, é difícil, por quem não se move, mesmo que, por uma concepção transcendente de existência, impor a permanência de um sofrimento cego e inútil a quem não tem mais motivos nem força suficiente para sustentá-la: se, isto é, as várias formas de "tratamento agressivo" às vezes perseguidos por médicos atraídos mais pela ânsia geral de experimentação que no interesse efetivo do paciente, são certamente para impedir, parece, ainda, que a liberdade de autodeterminação do doente consciente, seja no sobrepor-se volutariamente a gravosas curas de êxito incerto (relativo ao qual tenha dado o próprio "consenso informado"), seja, ao contrário, a recusar cada ulterior intervenção clínica que deva ser de qualquer forma tutelada. A possibilidade extrema, da intervenção da eutanásia ativa, não poderá ser, em perspectiva, e mediante uma adequada disciplina legislativa, integralmente excluída: também neste caso, esclarecida a situação objetivamente privada de esperança, e sobreposta à convicção do paciente consciente avaliado por mais sujeitos dotados de suficiente competência técnica (sobretudo sob o plano psicológico), onde evitar os perigos supra mencionados, não se deveria poder impedir ao sujeito de concluir dignamente a própria existência, com uma livre e adequada ajuda das mesmas estruturas de saúde e sem qualquer forma de envolvimento forçado (ou veladamente chantagista) nos confrontos dos sujeitos emocionalmente participantes (familiares ou amigos). Naturalmente 0 problema resta não resolvido pelos (frequentes) casos nos quais não estando o doente em condições de decidir sozinho, a escolha acaba sendo tomada por outros (em tal sentido uma comissão do Parlamento europeu 
aprovou por maioria, em 30 de abril de 1991, a proposta Schwarzenberg, favorável à eutanásia ativa; tal posição foi rejeitada aqui na Itália, com um parecer de 10 de junho do mesmo ano, do Comitê Nacional de Bioética: sobre a mudança o dossier feito por E. D'Orazio, in Notizie di Politeia, 1991, $n^{\circ}$ 22, pág. 3 ss.; sobre o tema merecem atenção as decisões da Alta Corte de Justiça da Inglaterra de 22 de março de 2002 [B. vs. NHS Hospital Trust], e da Corte européia dos direitos do homem de 29 de abril de 2002 [Pretty vs. U.K.], ambos reportados em Foro it., $\mathrm{n}^{\circ}$ 2/2003, com um artigo de G. CIMBALO; além disso, a sentença da Corte d'Assise d'appelo di Milano, de 24 de abril de 2002; o Comitê Nacional para a Bioética publicou depois um novo parecer sobre as "declarações antecipadas de tratamento" em dezembro 2003, consultável em www.governo.it: sobre o ponto R. PRODOMO, Le metamorfosi della salute nelle fasi iniziali e finali della vita, em Progressi biomedici, cit., pág. 11 ss., mas especialmente 19 ss., e A. PATRONI GRIFFI, Direttive anticipate: brevi note, ibidem, pág. 229 ss.). Trata-se obviamente de temas extremamente delicados, e de distinções fugidias: onde acaba, para um médico que assista um doente terminal de câncer, o tratamento paliativo (a "terapia da dor"), e onde inicia a eutanásia? E os argumentos, comumente usados, que impedem intervenções "artificiais" no ato procriativo, não poderiam aqui ser revirados, não só para proibir a eutanásia ativa, mas também para impôr àquela passiva, em consideração ao caráter não propriamente "natural" de um tratamento quimioterápico ou de uma intervenção cirúrgica destrutiva (quando, no entanto, os mesmos defensores de tais teorias recorrem com extremo cuidado quando eles se sentem em perigo, não se pondo definitivamente o problema da "naturalidade" do bisturi)? Como escreveu um filósofo do direito, o laico "não pode crer em um Deus capaz de comprazer-se dos extremos sofrimentos de um portador de câncer. Se Deus existe, certamente é um bom Deus sem um livro preto onde escreve o urro do moribundo e o ato de crueldade do médico. A aproximação laica não se baseia sobre o valor da vida, mas sobre o valor de uma vida que se possa dizer humana, a respeitar profundamente dentro e não além do tempo entre o primeiro aparecer e o último esplendor" (U. SCARPELLI, Eutanásia, l'ultimo gesto della pietà [1991], agora em ID., op. cit., pág. 129 e ss.). Na realidade, a ideia de um Deus de qualquer maneira bom se põe em uma perspectiva muito humana, mas este é um problema não enfrentável nesta sede; pelo ponto de vista jurídico, todavia, a perspectiva laica impõe a reprovação da concepção da vida individual como disponível somente pelo Ser criador. Ela deve permancecer na plena disponibilidade de quem a vive, e não de quem, neste mundo, se faça intérprete de uma presumida vontade divina; isto legitima em si a escolha do suicídio, tornando absolutamente intolerável cada sanção pela tentativa feita ao mesmo (salvo, obviamente, cada característica inerente aos danos produzidos a terceiros). Isso comporta, ainda, a possibilidade de escolher, pelo paciente, cada cura que esse entenda mais oportuna para a própria saúde, recorrendo a terapias alternativas em relação àquelas comumente 
propostas pela ciência médica; não importa, todavia, em uma mal entendida interpretação da garantia do art. 32 da Constituição Italiana, o direito de pôr ao encargo do Serviço Sanitário Nacional a despesa por terapias pelas quais não seja reconhecido um suficiente grau de eficácia. A limitação dos recursos disponíveis impõe ao último de destinar os próprios meios à oferta de curas experimentadas, cuja relação entre custos e benefícios seja otimizado (sobre o acontecimento do "método Di Bela", objeto de numerosas especulações políticas, veja-se as decisões $n^{\circ}$ 185/1998 da Corte Constitucional, em Giur. Cost., 1998, pág. 1510 ss., com observações de A. ANZON, e 121/1999, ibidem, 1999, pág. 1015 ss., sobre o problema da alocação de recursos sanitários, estritamente conexo com os princípios da igualdade e da justiça social, H.T. ENGELHARDT Jr., op. cit., pág. 383 ss.; E. LECALDAN, op. cit., pág. 275 ss.). Nesta perspectiva, todavia, o direito a morrer se põe como última expressão da dignidade da vida humana, e como determinação suprema de uma escolha de liberdade: o seu exercício concreto deverá obviamente ser remetido por inteiro ao sujeito, até que seja capaz de decidir conscientemente, além de tal limite, a decisão deverá ser presumida, mediante forma de eutanásia ativa, apenas a partir da avaliação conjunta dos médicos e familiares, com base em uma clara possibilidade de recuperação das condições mínimas de qualidade da vida do paciente.

\subsection{Aborto e Direito à Vida}

Sobre a questão do aborto se concentram muitas das questões que até aqui se apresentaram: o debate sobre - apesar de imperfeita e compromissória - Lei de 22 de maio de 1978, nº 194, já confirmada pelo êxito negativo de um referendum abrogativo, e de qualquer forma não afrontada pela citada lei, a $n^{\circ} 40 / 2004$, que (art. 14, parágrafos $1^{\circ}$ e $4^{\circ}$ ) sem prejuízo da vigência apesar da bem diversa inspiração, volta periodicamente a se reavivar sobre a onda das pressões das forças conservadoras e da concepção rígida das hierarquias do Vaticano na matéria (sobre a Lei citada, M. ZANCHETTI, La legge sull'interruzione della gravidanza, Padova 1992; para a doutrina católica veja-se, à luz de uma tradição antiga e constante do cristianismo, a constituição pastoral Garidium et Spes (1966), para a qual o abordo é "abominável delito" [ ${ }^{\circ}$ 51], ou a encíclica de Paulo VI Humanae vitae (1968), que inclui o aborto entre os meios ilícitos de controle de natalidade [ $\left.{ }^{\circ} 14\right]$ ). Sobre a licitude jurídica do aborto voluntário, instrumentalmente muitas vezes confundida com a ética, se refletem as concepções supra citadas em relação ao direito à procriação, do qual, portanto, o aborto representa o perfil negativo. A sacralização da vida humana induz os defensores da proibição à tentativa, provavelmente vã, de individuar o momento do surgimento da própria vida nas diversas fases de concepção, e em particular no encontro dos dois gametas, ou mesmo pela formação do embrião, que como dito, acaba por ser considerado de fato como sujeito de direito e tutelado como pessoa, em uma sumária equiparação do aborto e da destruição dos embriões para as práticas de inseminação artificial ao homicídio; daqui a 
solução (porém compromissória) de uma individuação convencional do nascimento do embrião ao décimo quarto dia da concepção (antes desse ponto se fala de pré-embrião, entendido como "totipotente": veja-se M. WARNOCK, A Question of Life. The Warnock Report on Human Fertilization and Embriology, Oxford 1985; outra e mais partilhável concepção torna o feto intangível a partir do momento no qual a formação do tubo neural põe o mesmo em condição de experimentar sofrimento). Mas tal reconstrução, além de colidir com toda realização efetiva de autodeterminação dos pais, se confronta, se for fundada na ideia da potencialidade, com a objeção de que cada elemento biológico destinado à procriação, do óvulo ao espermatozóide, deveria ser considerado, por si, digno de tutela e não destrutível: aqui a mesma "natureza", tão invocada pelos que sustentam a sacralização da vida, se encarrega, todavia, de demonstrar o contrário, conduzindo à eliminação dos óvulos não fecundados no ciclo menstrual (sobre esta característica P. SINGER, op. cit., pág. 122 ss.; H.T. ENGELHARDT Jr., op. cit., pág. 130 ss.; M. MORI, op. cit., págs. 54 ss. e 70 ss.; E. LECALDANO, op. cit., pág. 234 ss.; mas veja-se também, para uma clara exposição da doutrina afirmada pelas heranças católicas, a instrução Donum vitae [1987], onde a Congregação para a doutrina para a fé reafirma a equiparação entre aborto provocado e destruição de embriões). $\mathrm{Na}$ realidade, a concepção pela qual cada dimensão jurídica deve concentrar-se na determinação da "pessoa" (não na concepção deôntica católica, mas) no momento do nascimento, ou seja, no momento da separação do corpo do filho do da mãe (H.T. ENGELHARDT Jr., op. cit., pág. 140 ss., define cinco diversos significados do termo "pessoa"; sobre o ponto também M. MORI, op. cit., pág. 62 ss.) resulta a mais linear e a mais idônea relativa aos valores fundantes do modelo da democracia pluralista. O art. $1^{\circ}$ da Lei $n^{\circ} 194 / 1978$, reconhecendo, como objeto da tutela estatal, um "direito à procriação consciente e responsável", alem disso o "valor social da maternidade", tutela ainda a vida humana "desde o seu início". Tal fórmula, compromissoriamente aberta a múltiplas interpretações, se conecta à sucessiva, pela qual a interrupção voluntária da gravidez não é meio para o controle da natalidade: a essa pode recorrer a mulher "que acuse circunstâncias para as quais o andamento da gravidez, o parto ou a maternidade comportariam um sério perigo para a sua saúde física ou psíquica, em relação ou ao seu estado de saúde, ou as suas condições econômicas, ou sociais, ou familiares, ou às circunstâncias na qual ocorreu a concepção, ou a previsões de anomalias ou mal formações do concebido", dentro dos primeiros noventa dias de gravidez (art. $4^{\circ}$ ). A avaliação das circunstâncias compete ao aconselhamento e à estrutura médico-social competente, que examina com a mulher e, quando esta o consinta, com o pai do concebido, em relação à dignidade destes últimos, "as possíveis soluções dos problemas propostos", removendo o quanto possível às causas do prospectado aborto; ao término dessa fase e quando não ocorra motivo de urgência, o médico da estrutura, ou o médico de confiança, emitem um documento atestando o pedido da mulher, que, 
transcorrido sete dias, pode ser utilizado nas sedes autorizadas para obter a interrupção da gravidez (art. $5^{\circ}$ ). Além dos noventa dias, a interrupção é autorizada somente quando se atesta que a gravidez ou o parto comportam graves perigos para a vida da mulher, ou se revelam processos patológicos, como relevantes anomalias ou mal formação do nascituro, a ponto de determinar grave perigo para a saúde física ou psíquica da mãe (art. $6^{\circ}$ ). Os riscos de ambiguidade da lei em exame são evidentes, e refletem àqueles próprios da época de formação da mesma; só para apresentar um exemplo, a decisão resta em substância confiada somente à própria mulher, com admissão do pai (verdadeiro ou presumido) só com o consentimento da mesma. Se isto já é compreensível em caso de violência ou em qualquer outro caso liminar, o é muito menos no caso de divergência de opinião dentro do casal depois da concepção, talvez fortuita, e, contudo, relativa à esfera ética e jurídica de ambos os componentes da mesma.

Todavia, a inspiração de fundo permanece partilhável, e se baseia sobre um ponto absolutamente essencial, muitas vezes instrumentalmente negligenciada pelos opositores da opção legislativa: a interrupção voluntária é assim e permanece fruto de uma escolha, ou seja, o exercício de uma faculdade derivada do direito à procriação "consciente e responsável", e não uma obrigação da mãe ou do pai (essa diferença, muitas vezes, foge a quem quer transformar em proibições legislativas - ou seja, obrigações negativas - as próprias concepções éticas. Isso permite, enfim, remeter a responsabilidade da opção à esfera ética individual dos sujeitos envolvidos, tanto em fazer prevalecer, em cada um, a própria convicção moral, religiosa ou laica, inspirada em concepções transcendentes ou a leituras extremamente utilitaristas, à aplicação (mais ou menos conhecida) daqueles princípios de autonomia, beneficência, não maleficência e justiça, já descritos anteriormente. Em tal sentido, dita faculdade, ao contrário da proibição pretendida pelos críticos do aborto, se põe como única real possibilidade de aplicação correta dos princípios de autodeterminação individual que fundam a democracia pluralista, particularmente relevante em um âmbito que, como aquele procriativo, é atinente à esfera íntima da psicologia e da vida de cada um. Prescinde também pelas fundadas considerações relativas ao impacto social da escolha legislativa, ou seja, do efeito de redução (infelizmente não da eliminação) do triste fenômeno do aborto clandestino, ainda agora favorecido pelo uso da objeção de consciência dos sanitários, prevista pelo art. $9^{\circ}$ da Lei $n^{\circ}$ 194/1978, que, particularmente em algumas áreas do território nacional, resulta de fato impossível o exercício dos direitos previstos na mesma lei e deixa subsistir uma prática tanto ilícita quanto perigosa. O problema da licitude do aborto deve ser resolvido, com uma opção que se põe como expressão de uma preferência entre opostos valores em conflito, à luz do princípio da autodeterminação do indivíduo (e do casal genitor) em relação ao exercício de um direito à procriação consciente e responsável; tarefa dos poderes 
públicos em tal âmbito não pode ser aquela de imposição de comportamentos, mediante proibições ou obrigações, mas àquela de assegurar a máxima liberdade de escolha e o mais alto grau possível de segurança no plano sanitário para as práticas ligadas à interrupção (ou ao prosseguimento) da gravidez. Cada sumária equiparação do aborto ao homicídio, além de ser facilmente refutável - pelo menos até uma certa fase de evolução do embrião - sob o plano lógico e científico na impossibilidade de assimilação do indivíduo vindo à existência com a célula tronco, não produz efeitos decisivos sob o plano jurídico, pois pressupõe que a tutela da vida seja em sentido absoluto preferente sobre qualquer outro bem, segundo uma perspectiva que não pode ser considerada universal, e que entretanto não leva em conta as considerações supra acenadas em relação à indissociação da relação entre a vida e a morte no mesmo ato de geração. Mais uma vez, justo no momento do nascimento através do parto (porque ainda neste momento o ordenamento não pode colocar a linha divisória entre aborto e assassinato, sendo a tal ponto o recém-nascido definitivamente separado da mãe que o gerou e sujeito jurídico autônomo; no entanto a Lei no $194 / 1978$, ainda muito cautelosamente, reconhece o direito à interrupção da gravidez somente nos primeiros três meses de concepção, também em virtude da capacidade do feto de sofrer), cada opção não pode mais que investir na esfera privada dos indivíduos, deixando espaço às convicções de cada um, militaristicamente perseguindo o fim do menor sofrimento possível (sobre o tema H.T. ENGELHARDT Jr., op. cit., pág. 260 ss.).

\section{A EXPERIÊNCIA GENÉTICA E OS DIREITOS DAS GERAÇÕES FUTURAS}

No entanto, as perspectivas mais amplas e sugestivas, e ao mesmo tempo mais inquietantes, se encontram, como dito, em relação à rápida evolução das técnicas da manipulação genética, que mais do que outras se prestam a trazer benefícios (pense-se na potencial eliminação de determinadas patologias hereditárias) ou as degenerações de triste memória (a referência às pesquisas "eugênicas" dos médicos nazistas nos campos de extermínio é infelizmente inevitável).

Aqui, o conflito entre duas opostas exigências aparece claramente: de um lado o direito (e o subentendido interesse) ao livre desenvolvimento da pesquisa científica, garantido pela própria Constituição no $1^{\circ}$ parágrafo do art. 33, se põe como momento principal de evolução da coletividade, e responde a uma necessidade principal de melhora das condições de vida, conectando-se estritamente nesse âmbito ao direito à saúde, do art. 32 da mesma Carta; de outro, a tutela da segurança e da própria saúde pública impedem de abandonar a pesquisa de atividade incontrolada dos operadores insuficientemente preparados para compreender as consequências a curto e longo prazo, das próprias experiências. De outro lado, a pesquisa, por si, é sujeita a erros; mas os erros neste campo podem conduzir a resultados imprevisíveis, como a geração de seres monstruosos ou disformes, e, 
no entanto, autoconscientes e capazes de sofrer ou produzir sofrimentos, sobre o ponto, todavia, é, como dito, interventiva tanto a Lei $n^{\circ} 40 / 2004$ (art. 13, $3^{\circ}$ parágrafo), que proíbe a produção de híbridos e quimeras, quanto, indiretamente, a citada Convenção de Oviedo (art. 11 ss.) e o alegado Protocolo (art. $1^{\circ}$ ), que limitam os testes genéticos preditivos, e vetam as intervenções modificativas do genoma humano, ainda, a clonagem humana (a patenteabilidade de tais procedimentos foi vedada também pela Diretiva $n^{\circ}$ 98/44/CE do Parlamento europeu e do Conselho, de 06 de julho de 1998, sobre a proteção jurídica das invenções biotecnológicas, veja-se também o citado art. II-63 do Tratado que trouxe uma Constituição para a Europa).

A dificuldade está, ainda, no encontro de um equilíbrio entre os dois momentos, privilegiando, todavia, o aspecto da pesquisa e da evolução relativa a uma mal entendida tutela da identidade biogenética ou da segurança: esta última deverá, portanto, ser garantida mediante controles acurados sobre os centros de pesquisa, embora a noção de impossibilidade de dificultar as atividades que, mesmo que se reconheçam improdutivas ou perigosas, podem facilmente serem ocultadas ou transferidas para outros Países. Mais uma vez, do ponto de vista jurídico, a construção de direitos dirigidos a sujeitos futuros não parece levar a resultados significativos; na ausência de disciplinas específicas, ainda que em continuidade, as diversas formas de experimentação não parecem poder ser controladas por um apelo geral a situações subjetivas hipotéticas, como o direito do indivíduo futuro à própria identidade genética, ou, mais amplamente, o direito das gerações futuras a um meio ambiente saudável e não contaminado. Para o primeiro, de fato, não somente se opõem as objeções já postas em relação a não exercibilidade de tais direitos por parte dos sujeitos ainda não existentes, mas, também, uma vez aceitos os pressupostos, se opõe também a potencial antinomia entre um tal direito à identidade - além de dificilmente definível a priori, posto que dependente da própria escolha do genitor em ordem ao partner - e um direito - explicitamente garantido pela Carta Constitucional - à saúde, aqui entendida como expectativa de condições ótimas de vida física e psíquica, cuja violação acaba por dar razão ao "dano da procriação" do qual já se falou. Embora, é bom ver, também este último possa ser punido na mesma petição de princípio, em base de um suposto direito de "normalidade" posto em favor de um titular ainda não existente e, por conseguinte, de difícil construção, se não em (incerta) forma de uma responsabilidade do tipo aquiliano suportados pelo sujeito agente contra um sujeito futuro (considera não aceitável uma solução para o problema construída sobre um universo de pessoas futuras também E. LECALDANO 1999, pág. 251 ss.).

Do mesmo modo, o direito das gerações futuras relativos ao ambiente de vida pode ser certamente reconstruído em termos morais, mas se presta muito menos a uma definição satisfatória sob o plano jurídico: se pensado 
como direito à salubridade do ambiente relativo à globalização dos sujeitos existentes, esse é facilmente estabelecido como aspecto primário do direito à saúde do art. 32 da Constituição Italiana e pode ser bem aplicado para impôr obrigações ou proibições a indivíduos destinatários, constituindo também a base para a tutela dos interesses difusos; se concebido ao invés como vínculo e limite à ação da geração atual relativo às gerações futuras, esse pode justificar limitações só em ordem à potencial irreversibilidade de algumas escolhas, e ainda relativo à realização de um modelo específico de ordem institucional, ou seja àquele relativo aos princípios da democracia pluralista que, como dito, impede a realização de escolhas que não sejam modificáveis. Tal imposição, todavia, leva em conta essencialmente a possibilidade de revisão das próprias opções por parte da geração atual, e só mediatamente do princípio de não vinculabilidade das opções de sujeitos futuros; uma reconstrução mais notadamente baseada na titularidade dos direitos seria, ao invés, pouco sustentável, não sendo os sujeitos futuros em condições de exprimirem-se, nem de forma substituta (a equiparação de sujeitos não ainda existentes aos menores e aos incapazes, representados por tutores seria aqui dificilmente proponível, ainda mais quando trata-se de entidades coletivas como as gerações). Além disso, a configuração da identidade real dos sujeitos futuros depende da cadeia de escolhas efetuadas pela nossa e pelas próximas gerações e se põe por isso como momento de substancial intercambialidade dos indivíduos singulares, no estado atual só hipoteticamente configurados e ainda não definível como tal; vem menos o elemento de individualidade sobre o qual se funda a própria noção de identidade e, com essa, de tutela da mesma mediante a construção de direitos subjetivos (sobre o tema, de forma diversa, H. JONAS, II principio, cit., passim; D. PARFIT, Ragioni e persone [1989], trad. it. Milano 1993, pág. 447 ss.; R.M. HARE, Essays on Bioethics, Oxford, 1993, pág. 67 ss.; R. DWORKIN, II dominio della vita. Aborto, eutanasia e libertà individuale [1993], trad. it. Milano 1994; de recente, sobre características específicas A. SANTOSUOSSO, Individui e diritti: una prospettiva ancora valida in genetica?, em Progressi biomedici, cit., pág. 49 ss.; interessante também o confronto com outras culturas: um exemplo D. ATIGHETCHI, Clonazione e genetica nell'Islam, em Progressi biomedici, cit., pág. 173 ss.; o problema das gerações futuras é tratado, com perspectiva diversa das aqui adotadas, por R. BIFULCO, Futuro e Costituzione: premesse per uno studio sulla responsabilità verso le generazione future, em Studi in onore di G. Ferrara, I, Torino 2005, pág. 287 ss.); em tal sentido parece mais sustentável a ideia, estritamente fundada sob as perspectivas morais ao invés de jurídicas, da responsabilidade dos sujeitos presentes em relação às consequências - também a longo prazo - das próprias ações, no conhecimento da relação de causalidade que vincula as condições de vida dos sujeitos futuros às escolhas operadas no contexto atual (sobre o ponto E. LECALDANO, op. cit., pág. 254). 
Mais urgentes são ao invés os problemas legados ao uso das biotecnologias e ao seu desfrute comercial: a patenteabilidade das descobertas científicas que, classificadas como invenções, dizem respeito à manipulação genética de cada ser vivo, vegetal, animal ou humano, constitui um perigo não insignificante para o desenvolvimento futuro deste setor, certamente estratégico para o novo século, e para o exercício concreto dos direitos constitucionalmente garantidos à saúde e à vida. É de fato evidente que, também no que concerne à aplicação das novas biotecnologias às formas viventes não humanas, os reflexos sobre o ambiente e sobre as condições de vida do homem podem ser quase imediatas, e ainda se impõem controles (não limites ou proibições prévias) rigorosos, para assegurar o menor risco possível de erros gerados. Todavia, seja em relação a tal tipo de pesquisas, seja, sobretudo, em relação à reprodução em laboratório de sequências de DNA humano, a eventual possibilidade de registro de propriedade, se pode, certamente, constituir num importante incentivo para as empresas do setor ao investimento de capitais desmedidos em pesquisas muito caras, acabando, por outro lado, com a criação de posições dominantes de mercado mediante a qual o real acesso a determinada forma de terapia gênica seja de fato reduzida a poucos, privilegiados sujeitos, ou seja, levada à insustentáveis condições (sobre o tema, recente, M. RICOLFI, Bioetica, valori e mercato: il caso del brevetto biotecnologico, em Vários Autores, Una norma giuridica, cit., pág. 157 ss.; sobre o tema do registro de propriedade e da biotecnologia veja-se a decisão da Corte de justiça da Comunidade Européia de 9 de outubro de 2001 [Regno dei Paesi Bassi vs. Parlamento europeo, C-377/98]). O fenômeno se põe, por hora, essencialmente no campo agroalimentar dos alimentos "transgênicos" (ou melhor, O.G.M, organismos geneticamente modificados: nessa matéria veja-se a Diretiva $n^{\circ}$ 2001/18-CE, ao qual se adiciona o Regulamento CE $\mathrm{n}^{\circ} 1829 / 2003$, sobre alimentos e comidas geneticamente modificados, e a decisão da Comissão da União Européia de 19 de maio de 2004, sobre autorização de uso de milho da linha Bt11, geneticamente modificado), também com dimensões planetárias, poderia facilmente estender-se ao âmbito mais delicado das aplicações biomédicas quando forem, por exemplo, registradas sequências genéticas necessárias para a eliminação de determinadas doenças: obviamente isso poderia restar de fato insustentável cada consideração em relação ao benefício generalizado pela pesquisa do setor, em um campo, da saúde, onde particularmente odiosas são as desigualdades devidas à diversa condição econômica dos sujeitos. Sob a luz da já citada diretiva do Parlamento europeu ( ${ }^{\circ}$ 98/44/CE), todavia, já foi elaborado, durante a XIII legislatura, um projeto de lei depois caduco, no qual, além da nítida afirmação da proibição de modificar a identidade genética ou utilizar embriões humanos, se impedia toda forma de clonagem de seres humanos, excluindo-se o registro de propriedade de qualquer procedimento já finalizado; se vetava, ainda, o registro para aqueles procedimentos que objetivassem a modificar 
a identidade genética de animais, sempre que isso provocasse sofrimento inútil sob o plano científico, seja para o homem ou para os próprios animais. Posteriores exclusões da possibilidade de registro seriam possíveis introduzir com decretos interministeriais onde a intervenção biotecnológica e o seu desfrute comercial, contrastassem com os princípios de ordem pública e bom costume, tutela da saúde e da vida das pessoas e dos animais, preservação dos vegetais e prevenção de graves danos ambientais; uma avaliação de mérito seria esperada da Comissão interministerial para as biotecnologias e do Instituto Superior de Saúde. Se reconhecia, todavia, recebendo nisso a citada diretiva comunitária, a patenteabilidade de "uma invenção relativa a um elemento isolado do corpo humano ou diversamente produzido, mediante um procedimento técnico, mesmo se a sua estrutura é idêntica àquela de um elemento natural", contanto que a sua função e aplicação industrial fosse concretamente indicada, e com a condição de que o procedimento relativo fosse completamente disponível fora do corpo humano; o que deixava subsistir muitas perplexidades nos opositores de tais tipo de pesquisas. A proibição da clonagem é agora expressamente previsto no art. 13, parágrafo $3^{\circ}$, alínea ' $c$ ' da Lei no 40/2004 (e já no art. $1^{\circ}$ do Protocolo adicional da Convenção de Oviedo, ratificada na Itália com a citada Lei $\left.n^{\circ} 145 / 2001\right)$; se pode compartilhar, todavia, muito menos toleráveis são as proibições postas pela mesma lei, em ordem de pesquisa no campo biogenético, em particular sobre a não utilização dos embriões humanos para a pesquisa sobre células-tronco (através de uma proibição de produção de embriões com fim de pesquisa ou experimentação, art. 13, parágrafos $1^{\circ}$ e $3^{\circ}$, alínea ' $a$ '), âmbito do qual poderiam nascer, em um futuro próximo, novidades importantes para a cura de numerosas e graves patologias das quais são afetados sujeitos já em vida (e sobre as quais ainda, em outros países, se trabalha há tempo).

É evidente, como tais evoluções das biotecnologias, também provavelmente infreáveis e, portanto, acolhidas com atenção mas sem prejuízos, invistam diretamente nas bases da própria vida concreta de cada um e, ao fim, tendam a transformar a própria percepção profunda do evento da existência. As capacidades de intervenção sobre as origens da vida biológica assumem hoje proporções impensáveis, e o direito não pode não notar, tentando - de modo talvez vão - de estabilizar as expectativas de comportamento no âmbito de ação no qual a dimensão da ética individual, aquela da moral coletiva e aquela jurídica tendem a sobrepor-se, e nas quais, todavia, é assim mais importante ter distintas as esferas de permissão daquela de proibição, ampliando enquanto possível os espaços de autodeterminação dos indivíduos em relação àquele da intervenção coercitiva dos poderes públicos.

A vastidão, a variedade e a importância dos problemas emergentes no setor da bioética são tais que permitem, neste setor, só uma breve resenha: mas isto certamente evidencia o caráter peeminente de tais problemas na 
fase atual de desenvolvimento da civilização, segundo uma linha que vai bem além dos singulares ordenamentos e singulares constituições; no entanto, o início e o fim da vida, a colocação do homem em um ambiente do qual ele mesmo é parte essencial e não separada em uma presumida relação de domínio, a responsabilidade do indivíduo e da coletividade em direção a si mesma e em direção aqueles que o seguirão, são temas de reflexão que não podem restar confinados nas disputas filosóficas, nem podem ser abandonados às mecânicas e regras muito pouco futuristas de interesses econômicos de um mercado globalizado (sobre o tema, entre muitos, H. JONAS, II principio, cit., passim; S. RODOTÀ, Repertorio di fine secolo, Roma-Bari 1982, pág. 210 ss.; mas veja-se também as contribuições presentes no volume de vários autores, Questioni di bioetica, coordenado por S. RODOTÀ, Roma-Bari 1993).

Essas são mais do que uma das novas fronteiras do direito entendido como ciência prática, como instrumento para a absorção de conflitos e para a pesquisa de novos equilíbrios sociais; para essas questões o direito, e particularmente, o direito constitucional, agora também enfrenta, segundo os paradigmas próprios dos Países ocidentais, a um tipo de difusão planetária, podendo encontrar, repensando a própria relação com os momentos fundantes da existência humana, um dos terrenos de desenvolvimento mais férteis para a integração das culturas.

\section{REFERÊNCIAS BIBLIOGRÁFICAS}

CHIEFFI, Lorenzo. Ricerca Scientifica e Tutela della Persona. Bioetica e Garanzie Costituzionali. Edizioni Scientifiche Italiane: Napoli, 1993.

DWORKIN, Ronald. II Dominio della Vita. Aborto, Eutanasia, Libertà Individuale. Trad. Carla Bagnoli. Edizioni di Comunità: Milano, 1994.

ENGELHARDT JÚNIOR, Hugo Tristram. Manuale di Bioetica. Trad. M. Meroni. II Saggiatore: Milano, 1991.

JONAS, Hans. I/ Principio Responsabilità. Un'etica per la Civiltà Tecnologica. Trad. P. P. Portinaro. Einaudi: Torino, 1990. . II Diritto di Morire. Trad. P. P. Portinaro. Il Nuovo Melangolo: Genova, 1991.

LECALDANO, Eugenio. Bioetica. Le scelte Morali. Laterza: Roma-Bari, 1999.

MAZZONI, Cosimo Marco (org.). Una Norma Giuridica per la Bioetica. II Mulino: Bologna, 1998.

MORI, Maurizio. La Fecondazione Artificiale: questioni morali nell'esperienza giuridica. Giuffrè: Milano, 1988.

La Fecondazione Artificiale. Una Nuova Forma di Riproduzione Umana. Laterza: Roma-Bari, 1995.

MUSUMECI, Angela. Bioetica. in Enc. Giur. I.E.I.-G. Treccani: Roma, 1998.

NELSON, J. Robert. Bioetica. in Enc. Novecento, Supplementi, I, I.E.I.-G . Treccani: Roma, 1998.

PRODOMO, Raffaele (org.). Progressi Biomedici tra Pluralismo Etico e Regole Giuridiche. G. Giappichelli, Torino, 2004. 
RIMOLI, Francesco. Appunti per uno Studio sul Diritto alla Procreazione. in Studi in onore di M. Mazziotti di Celso. Cedam, Padova, 1995, II, pág. 465 e ss.

RODOTÀ, Stefano (org.). Questioni di Bioetica. Laterza: Roma-Bati, 1993.

. Repertorio di Fine Secolo. Laterza: Roma-Bari, 1992.

SCARPELLI, Uberto. Bioetica Laica (raccolta di scritti a cura di M. Mori). Baldini \& Castoldi: Milano, 1998.

SINGER, Peter. Etica Pratica. Trad. G. Ferranti. Guida: Napoli, 1989.

SPINSANTI, Sandro (org.). Bioetica e Grandi Religioni. Paoline: Cinisello Balsamo, 1987.

. Etica Biomédica. III edição. Paoline: Cinisello Balsamo, 1992.

Para outras indicações bibliográficas se envia aos referidos no conteúdo do texto. 